\title{
Supporting strategic decision- making on the future campus with space utilisation studies: a case study
}

Supporting strategic decisionmaking

Bart Valks

Management in the Built Environment, Faculty of Architecture, Delft University of Technology, Delft, The Netherlands

Elizabeth Blokland

Education and Student Affairs, Delft University of Technology, Delft, The Netherlands

Catelijne Elissen

Campus and Real Estate, Delft University of Technology, Delft, The Netherlands

Iris van Loon and Danko Roozemond

Education and Student Affairs, Delft University of Technology,

Delft, The Netherlands

Paul Uiterdijk

Campus and Real Estate, Delft University of Technology, Delft, The Netherlands, and Monique Arkesteijn, Alexander Koutamanis and

Alexandra Den Heijer

Management in the Built Environment, Faculty of Architecture, Delft University of Technology, Delft, The Netherlands

\begin{abstract}
Purpose - Across the world, many universities are dealing with a pressure on resources, caused by both organisational developments and ageing campuses. Space utilization studies have a strategic role, providing information on how space is being used, thereby informing decisions about the type and scale of facilities that are needed.

Design/methodology/approach - This study reports on the space use measurements conducted at TU Delft over the past five years, complemented by their use to make decisions about the university's real estate portfolio.

Findings - The education spaces of the university are found to perform well in terms of frequency rates and can be improved in terms of occupancy rates. The information helped to support short- and long-term decisionmaking. The study places of the university have a satisfactory occupancy in some types of study places, while in others there is room for improvement. More research is needed here to understand the relationship between space norms and space use.
\end{abstract}

(C) Bart Valks, Elizabeth Blokland, Catelijne Elissen, Iris van Loon, Danko Roozemond, Paul Uiterdijk, Monique Arkesteijn, Alexander Koutamanis and Alexandra Den Heijer. Published by Emerald Publishing Limited. This article is published under the Creative Commons Attribution (CC BY 4.0) licence. Anyone may reproduce, distribute, translate and create derivative works of this article (for both commercial and non-commercial purposes), subject to full attribution to the original publication and authors. The full terms of this licence may be seen at http://creativecommons.org/licences/by/4.0/ legalcode

The authors would like to thank all colleagues at TU Delft involved in conducting the space utilisation studies.

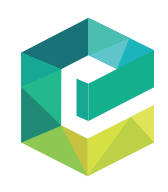

Property Management Vol. 39 No. 4, 2021 pp. $441-465$ Emerald Publishing Limited $0263-7472$ 
PM

39,4

Practical implications - The space utilization studies have supported discussions with the student council and decision makers on which interventions are required and which current facilities meet students' needs best. Originality/value - Not much space utilisation studies are reported in the academic literature, and those that do have several limitations. This study may serve as a best practice for benchmarking by other universities and as evidence in other research for the planned and actual use of university facilities.

Keywords Decision-making, Property management, Supply and demand, Real estate, Space utilization, Campus management

Paper type Research paper

\section{Introduction}

Across the world, many universities are dealing with a pressure on resources caused by organisational developments, student growth and ageing campuses. First, universities are faced with an increasingly uncertain demand (both qualitatively and quantitatively) for facilities. An increasing share of international students results in a more uncertain student influx (OECD, 2019) and a more diverse demand for student facilities and services on-campus (Sankari et al., 2018; TU Delft, 2016). Furthermore, as securing research funding from public or private sources is increasingly competitive in "academic capitalism" (Lepori and Reale, 2019; Schulze-Cleven and Olson, 2017), there is competition for resources. This results in more temporary contracts and uncertainty in the demand for offices and laboratories. Second, the modernisation of many campuses is a challenge. Many campuses in Europe and the United States consist largely of ageing buildings that are often in need of renovation and therefore (re)investment (Den Heijer and Tzovlas, 2014; Kadamus, 2013). Combined with reduced government funding, this leads universities to consider alternative financing models (Newell and Manaf 2017; McCann et al., 2018).

Space utilisation studies have a strategic role in campus planning (Space Management Group, 2006b): they provide information on how space is being used, helping to inform decisions about the type and scale of facilities that are needed. However, these studies are not often shared across institutions or in the academic literature, and it is unknown to what extent universities even conduct them. In this paper, we report on a current practice of space utilisation studies and their use in decision-making in campus management. This study is novel in three ways when compared to the studies reported in the literature:

(1) It covers a whole portfolio across multiple years.

(2) It relates the outcomes to the space norms of the institution and decision-making based on the outcomes of the study.

(3) It clearly states the setup of the utilisation study.

The main research question of this paper is: what is the space use of education spaces and study places at TU Delft, and how does it inform campus decision-making? To answer this question, a case study research is conducted. First, the theories underlying the research are discussed, followed by related work on space utilisation studies. Then, the case is introduced, followed by an analysis of the space use of the education spaces and study places and how these results informed decision-making at the university. Finally, the paper is concluded.

\section{Conceptual model}

The study of decision-making about the university campus is "campus management", to which broader Corporate Real Estate Management (CREM) theories apply (Den Heijer, 2011). In CREM, decisions are made through a continuous process in which users' demands are matched to the organisation's accommodation (De Jonge et al., 2009). This process is called "alignment". Although much is written on alignment, it is still considered a "long standing 
problem” in CREM theory (Arkesteijn, 2019; Heywood, 2011). Heywood and Arkesteijn (2018) find through a study of the literature that the alignment models are different in their conceptualisation. Of interest here is that the cognitive objects to be aligned differ across studies: three business objects and three real estate objects are aligned. Business objects are strategy, performance or needs of the business. Real estate objects are the real estate strategy, the real estate organisation or real estate itself (a real estate portfolio or objects). When the "alignment" problem in CREM concerns aligning CRE objects to the CRE organisation a central question is: how much space does the organisation need and of what quality? The answer to this question is given by evaluating the use of current space combined with future forecasts in order to plan new building, renovation or disposal. An example of how to align education spaces to the needs of the business is given by Arkesteijn et al. (2015).

The constant process of matching the demands of users on-campus to the available spaces happens on multiple time horizons (De Jonge et al., 2009). With regard to education spaces, Beyrouthy et al. (2008) distinguish three time horizons: space planning to design new campuses and buildings (5-50 years), space management to remodel existing space (1-5 years) and course timetabling to allocate events to times and rooms ( $<1$ year). The choices made in each of these time horizons have consequences for the others. Particularly the relationship between space norms and space utilisation is of interest (Figure 1). For example, a campus with a high amount of space per user (e.g. a high amount of study places per student) is likely to have a low utilisation, and vice versa. The chosen norms partly determine space utilisation, and in turn space utilisation can inform the chosen space norms. However, there is a limit to the explanatory value of space utilisation. For example, in case of high space utilisation rates, users may make other decisions: students may study at home, find alternative locations or not study at all.

To further clarify the relationship between space norms and space utilisation, we use the body of knowledge from the UK as primary reference, as it is well-documented and commonly referred to in literature.

\subsection{Space norms}

Traditionally, space planning and allocation in the UK higher education sector was done according to space norms, which are still used in modified forms (Downie, 2005). The space norms in the UK were established in UGC (1987) and PCFC (1990) (Space Management Group, 2006a). These norms are expressed as useable areas in $\mathrm{m}^{2}$ per FTE student for 20 different subject areas, e.g. humanities and engineering (Space Management Group, 2006a, p. 19). The UGC and PCFC norms were drawn up based on assumptions and observations, termed the underlying "coefficients":

(1) Total hours of on-campus contact or learning hours per week per student;

(2) Breakdown of those hours into different types of activity, for instance lecture theatre hours, seminar hours and laboratory hours;

(3) Total hours that space is available per week to be used, for instance 40 hours;

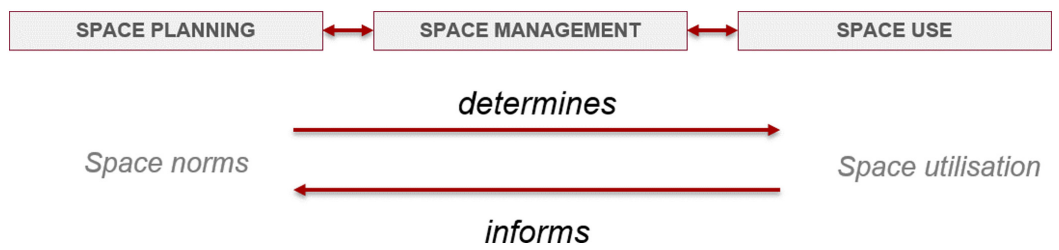

Supporting strategic decisionmaking

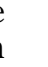


PM

39,4

444

(4) Predicted frequency and occupancy rates for space use, that is planned utilisation;

(5) Space standards per workplace in teaching, learning, research and support spaces;

(6) Definition of discrete subject groups or disciplines;

(7) Staff: student ratios by discipline or subject group;

(8) Professorial: other academic staff ratios by subject group;

(9) Academic: support staff ratios by subject group;

(Space Management Group, 2006a)

It depends on the space type which coefficients are most influential. For education spaces and study spaces the coefficients 1-6 are relevant, whereas staff ratios are of less influence. For offices, the coefficients 3-9 are relevant and on-campus contact and its breakdown to a lesser extent. However, student staff ratios and on-campus contact are connected: the coefficients thus not only influence the norms but also influence each other.

Space Management Group (2006a) reviewed the established space norms, comparing the actual space norms in place in 1991-1992 to those in place in 2003-2004, based on the size of the estate and student and staff numbers. The study found that in 2003-2004, the sector operated at $80 \%$ of the space norms set in the UGC report. Furthermore, they identified that the coefficients underlying the space norms have changed. With regards to studying the coefficients, the authors remark: "without an assessment of this type, it is difficult to know whether an HEI, or any organisation, has broadly the right amount and type of space." (Space Management Group, 2006a)

\subsection{Space utilisation}

For a definition of space utilisation, the literature mostly refers to NAO (1996):

$$
(\% \text { frequency } x \% \text { occupancy }) / 100=\text { space utilisation rate }
$$

Frequency is the number of hours a room is in use as a proportion of total availability (the timetabled week);

Occupancy is the average group size as a proportion of total capacity for the hours the room is in use.

As described in the previous section, predicted frequency and occupancy rates for space use were named as coefficients to underpin space norms, as is the total availability. Space Management Group (2006b, p. 6) adds to this the notion that "utilisation may be calculated as planned utilisation based on assumptions about how space will be used, for instance using data from timetables or assumptions about projected levels of use in a new building. Alternatively, it can be a measure of how space is actually being used, based on observation." Thus, there are four variables to be measured - in this paper, they are named as follows: (1) scheduled frequency, (2) scheduled occupancy, (3) actual frequency and (4) actual occupancy (Figure 2). These four variables give a comprehensive insight into the use of space:

(1) The scheduled frequency rate shows to which \% of its availability a space has been booked prior to observations. The performance on this variable gives a strong indication to if there is enough space available in the portfolio;

(2) The actual frequency rate can be compared to the scheduled frequency rate to show which bookings do not take place ("no-shows") or where unscheduled meetings take place. This comparison will provide actionable insights. For education spaces it will pinpoint where no-shows have occurred, which can serve as input to improve the 


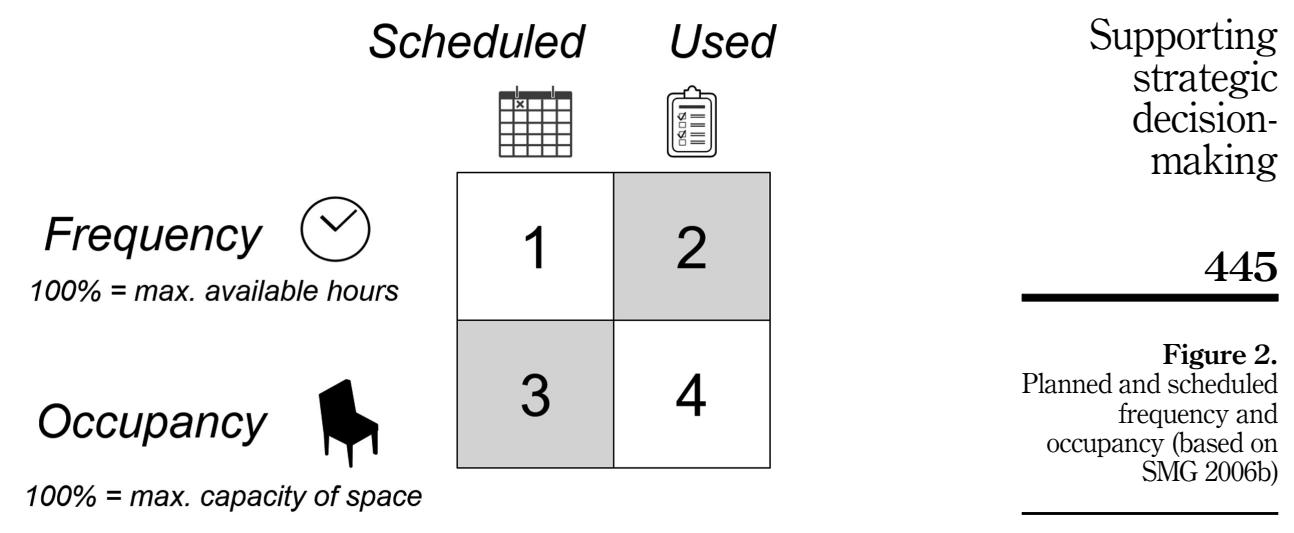

schedule in the next academic year. It can also show where unscheduled meetings take place and how large this demand is, sharpening the initial insight.

(3) The scheduled occupancy rate shows for which group sizes each room is reserved. The performance on this variable gives a strong indication to if the available spaces are of the right sizes, or if there are many over- or undersized spaces in the portfolio that are consequentially poorly utilised;

(4) The actual occupancy rate can be compared to the scheduled occupancy rate or measured standalone. This information can be used to improve planning assumptions, especially in education spaces.

It is important to note that although neither NAO nor SMG address it explicitly, the definition of space utilisation assumes the room as the object of measurement: frequency describes its availability and occupancy describes its use of capacity. However, in office areas and study spaces, the object of measurement is a workplace. Here, the frequency and occupancy are essentially the same because the value of the capacity can only be 0 (free) or 1 (occupied). In measurements where workplaces are the unit of measurement, we refer to the measured variable as scheduled or actual occupancy.

In the literature, different targets are set for frequency and occupancy rates. NAO (1996) writes that the PCFC set targets of 80\% frequency and 80\% occupancy for teaching space. Whether this pertains to predicted or actual use is not stated explicitly, although their relation to the auditing of space implies actual use. TEFMA (2009) provides targets for a range of space types, of which the most have targets of $75 \%$ frequency and $75 \%$ occupancy. It is stated that these targets are for an average week of 67.5 hours and they seem to relate to actual use. NAO writes that in practice, achieving frequency and occupancy rates above $70 \%$ may already be challenging. Selecting targets may depend on the previously detailed coefficients. However, making explicit if targets pertain to predicted or actual use is important, as difference between them can be significant (Space Management Group, 2006b).

\section{Related work}

There has only been limited research documenting space utilisation at universities, even though there is a clear need to share and benchmark data across institutions. This need is identified both by campus managers (Den Heijer, 2011) and by researchers. Alghamdi (2017) gives two explanations for the limited availability: the high costs of conducting utilisation 
PM

39,4

\section{6}

studies and a belief by practitioners that other variables are more useful indicators than space utilisation. A third possible explanation is that there is a lack of sharing space utilisation studies outside of the own organisation.

Table 1 shows the space utilisation studies found in the literature and their characteristics. Four of these studies were conducted in education spaces and two in study spaces. Only two studies were done across multiple buildings. Because utilisation levels can vary greatly between buildings, studies across whole portfolios are expected to deliver more value in terms of benchmarking.

Furthermore, Table 1 shows each study's objective and the mention of space norms $\left(\mathrm{m}^{2}\right.$ per user or workplaces per user) in the article. The objectives show that the reasons to conduct the studies are different. The studies focussing on study places seem to be more usercentric, focussing on how future growth can be accommodated and if the spaces support students. Conversely, the studies on education spaces are more real estate-centric, focussing on improving effectiveness and efficiency, providing guidelines for future space provision or developing a space charging model. Surprisingly, only two studies make mention of space norms. Organ and Jantti (1997) make note of both the current amount of seats per 100 FTE students and the figure that was used during discussions of extension of the library building. Alghamdi (2017) lists the current space area per FTE student. Similarly, with regards to the coefficients, only Organ and Jantti (1997) make mention of some coefficients that underpinned the space norms for their Library building, but they are other coefficients than identified in section 2.1. This is a surprising finding - even though many authors have the objective of relating the outcomes of their studies to decisions about accommodating growth or

\begin{tabular}{|c|c|c|c|c|c|c|c|}
\hline Authors & Year & Country & $\begin{array}{l}\text { Space } \\
\text { type }\end{array}$ & $\begin{array}{l}\text { Study } \\
\text { object }\end{array}$ & Objective & $\begin{array}{l}\text { Space } \\
\text { norms }\end{array}$ & $\begin{array}{l}\text { Space } \\
\text { coefficients }\end{array}$ \\
\hline $\begin{array}{l}\text { Organ and } \\
\text { Jantti } \\
\text { (1997) }\end{array}$ & 1997 & Australia & $\begin{array}{l}\text { Study } \\
\text { places }\end{array}$ & $\begin{array}{l}\text { Library } \\
\text { building }\end{array}$ & $\begin{array}{l}\text { Recommend } \\
\text { strategies to } \\
\text { accommodate } \\
\text { future growth } \\
\text { and development }\end{array}$ & Yes & $\begin{array}{l}\text { Other } \\
\text { coefficients }\end{array}$ \\
\hline $\begin{array}{l}\text { Khoo et al. } \\
\text { (2014) }\end{array}$ & 2014 & England & $\begin{array}{l}\text { Study } \\
\text { places }\end{array}$ & $\begin{array}{l}\text { Library } \\
\text { building }\end{array}$ & $\begin{array}{l}\text { Understanding if } \\
\text { the Library } \\
\text { supports } \\
\text { student's goals }\end{array}$ & $\begin{array}{l}\text { Not } \\
\text { mentioned }\end{array}$ & None \\
\hline $\begin{array}{l}\text { Ibrahim } \\
\text { et al. (2011) }\end{array}$ & 2011 & Malaysia & $\begin{array}{l}\text { Teaching } \\
\text { space }\end{array}$ & $\begin{array}{l}\text { One } \\
\text { building }\end{array}$ & $\begin{array}{l}\text { To develop a } \\
\text { space charging } \\
\text { model for the } \\
\text { university }\end{array}$ & $\begin{array}{l}\text { Not } \\
\text { mentioned }\end{array}$ & None \\
\hline $\begin{array}{l}\text { Kasim } \\
\text { et al. (2012) }\end{array}$ & 2012 & Malaysia & $\begin{array}{l}\text { Teaching } \\
\text { space }\end{array}$ & $\begin{array}{l}\text { One } \\
\text { building }\end{array}$ & $\begin{array}{l}\text { To provide a } \\
\text { guideline for } \\
\text { future space } \\
\text { provision }\end{array}$ & $\begin{array}{l}\text { Not } \\
\text { mentioned }\end{array}$ & None \\
\hline $\begin{array}{l}\text { Abdullah } \\
\text { et al. (2012) }\end{array}$ & 2012 & Malaysia & $\begin{array}{l}\text { Teaching } \\
\text { space }\end{array}$ & $\begin{array}{l}\text { University } \\
\text { Campus }\end{array}$ & $\begin{array}{l}\text { A basis for action } \\
\text { to improve space } \\
\text { efficiency and } \\
\text { effectiveness }\end{array}$ & $\begin{array}{l}\text { Not } \\
\text { mentioned }\end{array}$ & None \\
\hline $\begin{array}{l}\text { Alghamdi } \\
\text { (2017) }\end{array}$ & 2017 & $\begin{array}{l}\text { Saudi } \\
\text { Arabia }\end{array}$ & $\begin{array}{l}\text { Teaching } \\
\text { space }\end{array}$ & $\begin{array}{l}\text { Five } \\
\text { buildings } \\
\text { (one per } \\
\text { campus) }\end{array}$ & $\begin{array}{l}\text { To identify how } \\
\text { space can be } \\
\text { effectively and } \\
\text { efficiently } \\
\text { operated }\end{array}$ & Yes & None \\
\hline
\end{tabular}

Table 1.

General characteristics of space utilisation studies 
increasing efficiency and effectiveness, they have difficulty connecting it to the planning assumptions that are the basis for those decisions.

Next, Table 2 shows the specifications of the space utilisation studies provided by the authors. First, it shows if the studies make a distinction in their measurements between frequency and occupancy, scheduled and actual. For the studies conducted in study places, only the actual occupancy is relevant. For the studies in teaching space, none of the studies measure both scheduled and actual space use. Abdullah, Ali, and Sipan (2012) and Kasimet al. (2012) study space use based on scheduling data. Ibrahim et al. (2011) imply the use of scheduled frequency in their definition of frequency (hours used/hours booked) [1], but do not specify what the scheduled frequency rate is, nor how it is collected. Only Alghamdi (2017) addresses the distinction between scheduled and actual use, although his experiment is based on scheduling data and thus only reflects scheduled frequency and occupancy rates.

Table 2 further shows the measurement period, duration, amount of observations and the maximum availability used to calculate frequency. The table shows that often these details are not provided to full extent. Either the measurement duration, the amount of daily observations or the maximum availability are unclear. In Khoo et al. (2014), all of these details are absent: although they state a total of 112 surveys are carried out, the division of those surveys into observations per day and duration of the measurement in days is not specified. Only the measurement period is clear in all studies, e.g. four semesters or a one-time study of three months. Organ and Jantti (1997) are an exception - they provide clear statements on all aspects. As has been observed by Space Management Group (2006b), the variability in conducting space utilisation studies makes comparison difficult. Table 2 confirms this variability amongst academic studies.

To conclude, this section demonstrates that past utilisation studies have some limitations: most studies do not cover a whole portfolio, most studies do not relate the outcomes to planning assumptions (and consequently decision-making) and most studies are not clear about the setup of their utilisation study. The study reported in this paper satisfies all these requirements: it covers a whole portfolio over multiple years, it relates the outcomes to planning assumptions and decision-making and it details the study setup.

\section{Research methods}

In order to answer the main research question, a case study design is chosen, as it focuses on the extensive exploration and understanding of a phenomenon, rather than confirmation or quantification of it (Kumar, 1999). The case that is studied in this paper is the portfolio of education spaces and study places at TU Delft. What is studied is the space use of this portfolio and how this information informs decision-making with regards to the portfolio.

Because the match between the demand for and supply of education spaces changes every year, it is necessary to collect data over a long period of time and use quantitative and qualitative research methods. Data on space utilisation are collected each year via surveys and analysed and compiled in reports. These surveys follow the guidelines for space utilisation studies which can be found in NAO (1996) and Space Management Group (2006b) (see section 2). Then, the relationship of the surveys to decision-making is studied ex-post through document analysis.

This study adheres most to Yin's (2002) conceptualisation of a case study design, as described by Yazan (2015). However, with regards to epistemology and validity a constructivist perspective is followed, as in Stake (1995) and Merriam (1998). Ultimately, the objective of the paper is to present a case of an organisation that uses space utilisation studies to inform its decision-making. When it comes to space utilisation studies, the objective of the study is to determine the space use as objectively as possible. However, the registration of this data is done by humans and subject to interpretation and mistakes. To ensure
Supporting strategic decisionmaking 
PM
39,4

448

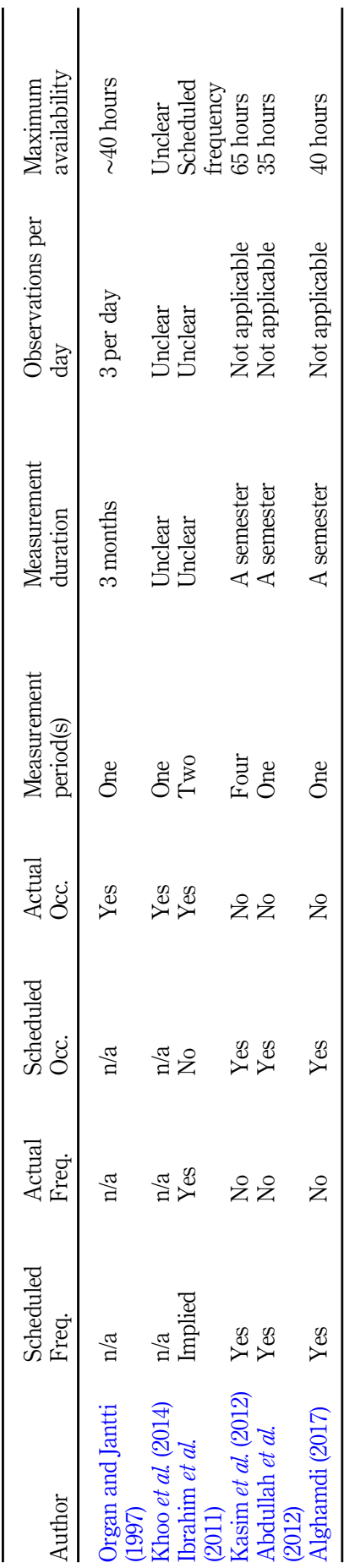

Table 2.

Data collection

specifications of space utilisation studies 
reliability and validity of the survey and its results, the data collection and analysis are based on prior work on the subject and applied consistently throughout the survey. To increase external validity, a detailed description of the data collection is provided here, as this was found to be a limitation in prior research. The survey includes measures to reduce surveyor bias. In the analysis, comparison to scheduling data and to previous studies provided additional checks. Finally, when reporting the survey outcomes, various university stakeholders were involved before finalising the outcomes.

When it comes to analysing how these surveys inform decision-making, the notion of reality is more subjective. Here, document analysis is used as primary method with the purpose of tracking the development in decision-making (Bowen, 2009). The studied documents are policy documents and memoranda. The resulting text has been checked with several co-authors of this paper, who together with the main author have worked together on the university's policies for education spaces and study places as well as the initiation and development of projects.

The survey is set up as follows. Each year, all the university's shared education spaces are surveyed during peak periods. The number of study places surveyed differs throughout the years (see section 6.2) and surveyed during exam weeks. The objective of both surveys is not to infer the use of the spaces throughout the whole portfolio for the whole year but to understand the space use during the busiest time of the year. Throughout the years, the measurement duration and the number of daily observations have changed: due to additional information demands the measurement duration was increased and later due to budget constraints the measurement duration and observations were decreased. Table 3 summarises the properties of the space utilisation studies.

The following steps were taken in the data collection process:

(1) First the spaces to be surveyed, the number of daily observations, and the measurement duration are determined. A template is made in MS Excel for recording observations;

(2) During the measurement period, several surveyors (students) are tasked to walk past all the education spaces or study places to make observations. Each surveyor covers several buildings within a set observation period (1 hour or 2 hours) and repeats this 4-8 times a day depending on the observations per day.

(3) Each observation is either a 0 (empty), a NS (no-show) or a count of the number of students in the room. Empty means that there is no event scheduled. A no-show means that an event was scheduled in the space, but the space was empty. This only applies to education spaces. In case no observation is made, a "no registration" is indicated.

\begin{tabular}{|c|c|c|c|c|c|c|c|c|c|}
\hline \multirow{2}{*}{$\begin{array}{l}\text { Properties } \\
\text { Measurement period }\end{array}$} & \multirow[b]{2}{*}{2015} & \multicolumn{3}{|c|}{ Teaching space } & & \multicolumn{3}{|c|}{ Study places } & \\
\hline & & 2016 & 2017 & 2018 & 2019 & 2017 & 2018 & 2019 & \\
\hline Scheduled frequency & & & Yes & & & & N/A & & \\
\hline Actual frequency & & & Yes & & & & N/A & & \\
\hline Scheduled occupancy & & & No & & & & N/A & & \\
\hline Actual occupancy & & & Yes & & & & Yes & & \\
\hline Measurement duration (weeks) & 6 & 9 & 8 & 4 & 4 & 3 & 2 & 2 & Table 3. \\
\hline Observations per day & 8 & 8 & 8 & 8 & 4 & 8 & 8 & 4 & Properties of the \\
\hline Frequency baseline & & & 40 & & & & 40 & & reported study \\
\hline
\end{tabular}


The data collection and analysis of the space utilisation studies evolved throughout the years.

The data collection varied in measurement duration and observations, and the data analysis expanded by tailoring to specific needs. To make the connection to the use of the data in decision-making, the data analysis in this paper is done based on a document analysis. Both the reported data and comparable data across years are shown. The steps in the data analysis are the same each year:

(1) Determine the scheduled frequency and occupancy. The timetable of each space for the duration of the measurement period is downloaded after the measurement period ends. The scheduled frequency is determined per education space per week, by dividing the sum of the duration of all activities in a week in a space by the number of hours that the space is available. The scheduled occupancy could also potentially be extracted from this document; however, using the data of the estimated group sizes for this purpose was deemed unreliable by the scheduling department. Because the university does not require students to enrol for activities and there is no required attendance, group sizes are estimated using different methods.

(2) Determine the actual frequency. For each education space, the number of no-shows that is counted for one week is subtracted from the scheduled frequency during that week.

(3) Determine the actual occupancy. The actual occupancy is determined by taking the average count of students for all counts that are equal or larger to 1: these are all activities which have taken place, or the moments that study places were occupied during a week. The average of these counts divided by the maximum capacity of a space is its actual occupancy.

\section{Case}

\subsection{Case introduction}

The TU Delft is a technological university in Delft, The Netherlands. The university was founded in 1842 and consists out of eight faculties which organise the university's education and research. The support services provide supporting functions for the faculties - relevant to this paper are the departments of Campus and Real Estate (CRE), Education and Student Affairs (ESA) and Information and Communication Technology (ICT). Both the faculties and the support services are headed by an Executive Board which oversees the daily operation of the university and which makes most decisions at the university, and a Supervisory Board that supervises the Executive Board.

The TU Delft houses most of its activities on its campus, located south of Delft's city centre. The university's campus comprises of 161 hectares of land. The distance between the northernmost and southernmost faculty building is around two kilometres. Most faculties have their own main building, and in some cases they have additional buildings. The university's education spaces and study places are located both within faculty buildings and within shared education buildings.

TU Delft organises all its education in an academic year that starts in September and ends in July: see Figure 3. The academic year is divided into two semesters, which are each split into two-quarters. A quarter consists out of ten weeks. Education takes place from week 1 to week 7 or 8; week 8, 9 and 10 are focused on exams and preparation [2].

At TU Delft different types of education spaces and study places are distinguished. Plate 1 shows the four types of education spaces suitable for general use. These spaces are grouped together in the sense that they are scheduled centrally and used by all faculties. Within types there are some variations depending on group sizes and spatial configurations. Plate 2 shows 


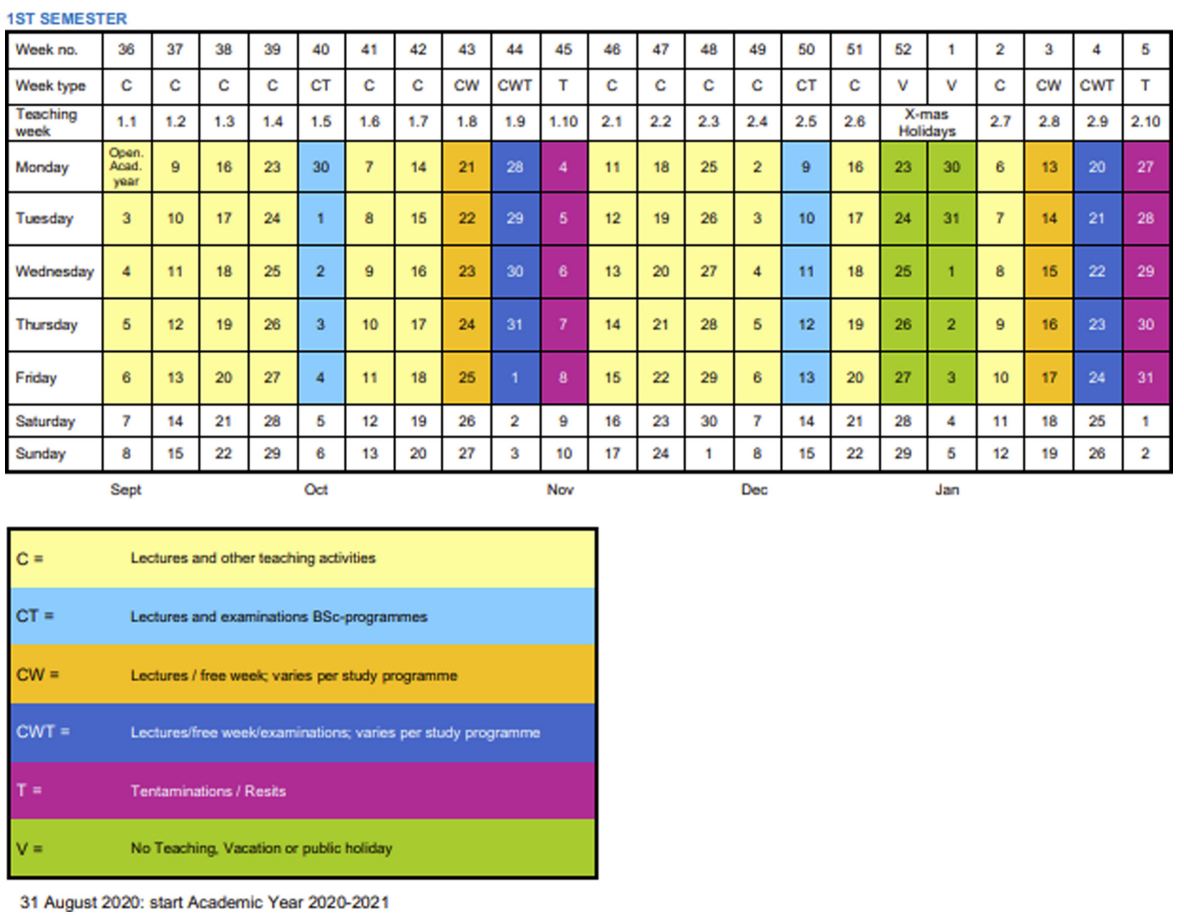

Supporting strategic decisionmaking

Figure 3.

A typical academic year calendar for one semester (TU Delft)

the three types of study places. There are spaces for longer periods of self-study (categorised as type A, or A2 if it has a desktop PC), short periods of studying ("touchdown") (type B, or B2 if it is in a classroom) or collaboration (type C). The functional and technical requirements of these spaces are outlined in a program of requirements called the "Cookbook" (TU Delft 2018).

\subsection{Policy developments}

This subsection summarises the relevant developments in policy making at the university. The policy making on this topic is a collaboration between ESA, CRE and ICT, supported with analyses and by feedback from students and lecturers.

In July 2014 the "Roadmap Education Spaces" was established. This document is a framework for decision-making on renovation, disposition or construction of education spaces. It outlines the university's forecast for the student population, the expected future demand for education spaces, requirements for education spaces and scheduling and the governance. Relevant conclusions are:

(1) The student population will continue to increase to a peak and stabilise around 20,000 students in 2020;

(2) There will be an increased demand for classrooms suitable for active learning as education programs will move towards interactive forms of teaching;

(3) To facilitate active learning and ease of use for lecturers there is a need for standardisation of the audio-visual facilities in education spaces. 
PM

39,4

\section{2}

\section{Plate 1.}

Different types of educations spaces: frontal didactics (top left), mixed didactics (top right), collaboration (bottom left), examination (bottom right)

Plate 2.

Different types of study places: self-study places (left), touchdown places (middle) and meeting places (right)
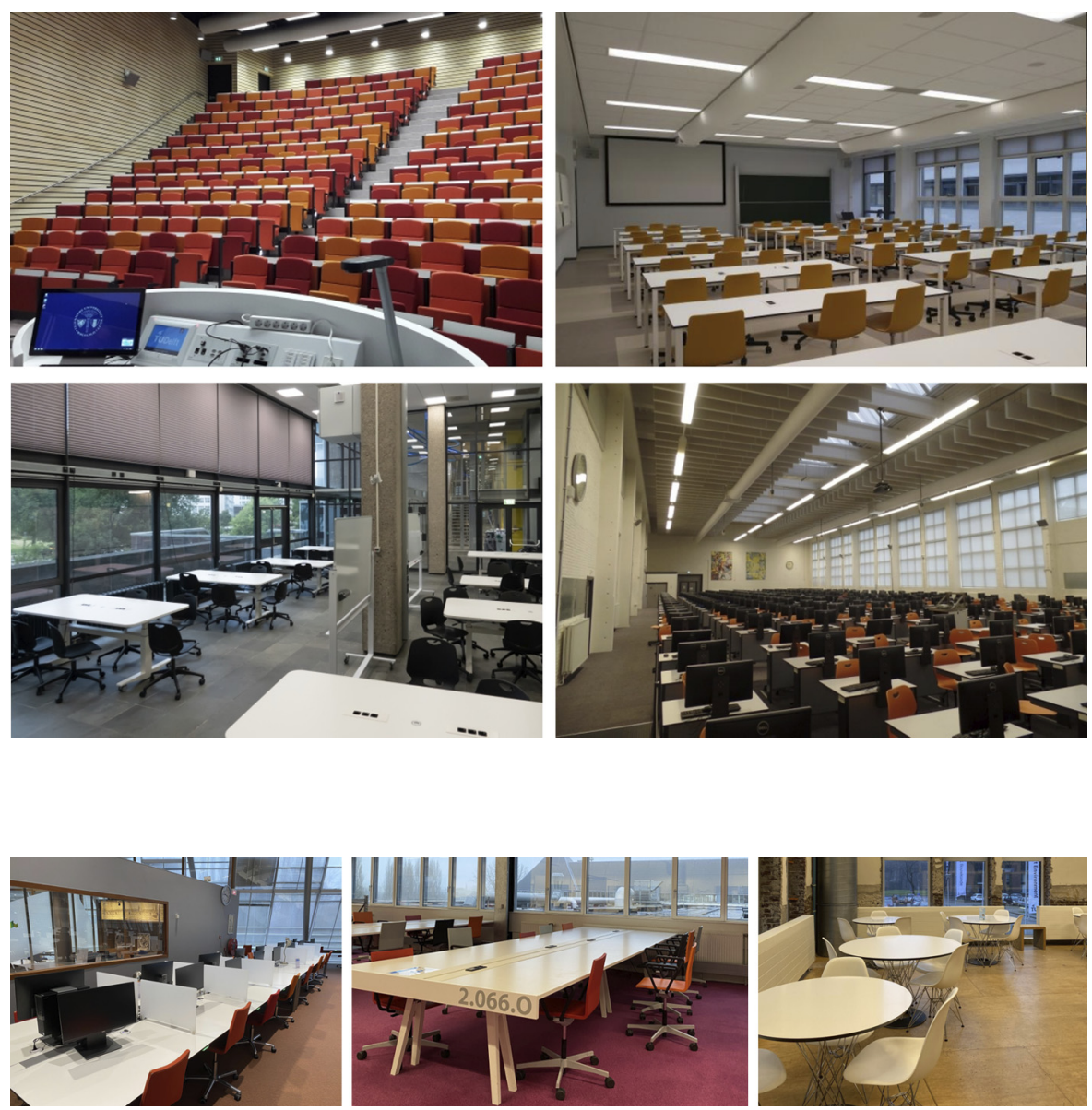

Based on these recommendations, a "Transformation plan" was made, a plan outlining the adjustment of education spaces to fulfil these requirements. This document was established in February 2016. The transformation plan builds on the Roadmap:

(1) It contains an analysis that shows for which types and sizes of education spaces there is a shortage. The two largest shortages are in classrooms for $90-120$ people and lecture halls for more than 600 people. It proposes an investment to build spaces to reduce these shortages.

(2) A program of requirements (“Cookbook") is made together with lecturers, describing the requirements of each education space (by type and size) - see section 5.1.

(3) It contains an investment plan to transform all existing spaces to meet these requirements.

(4) For study places a similar plan is made together with the student council. The amount and type of study places on-campus is determined - see section 5.1. For each type, requirements are set. An investment is proposed to transform existing study places. 
In February 2017, the transformation plan was adjusted to account for an updated student population forecast: it was aligned to an increase towards 25,000 students in 2025 rather than the previous forecast which predicted a stabilising population of 21,500 in 2020. In June 2017, a proposal "Terms of Reference education spaces and study places" was made, outlining the opportunities to optimise education logistics (and thus reduce the demand for education spaces). This proposal was made in reaction to the updated student population forecast, which required an estate strategy that made more efficient use of existing spaces on-campus. The proposal outlines several improvements to the education logistics, which are expected to reduce the demand for education spaces by $10 \%$ : from 0.9 to 0.81 seats in education spaces per student and from 0.25 to 0.23 study places per student.

Since 2018, a document called the Progress monitor is made each year, describing the progress on the ambitions stated in the transformation plan. It reports on three components: satisfied users, efficient space use and sufficient space for growth. Specifically relevant for this paper is efficient space use. Here, the stated goals for all shared education spaces are $75 \%$ scheduled frequency, a $5 \%$ no-show rate and at least $60 \%$ scheduled occupancy. No targets are mentioned for study places.

\section{Space utilisation studies}

\subsection{Education spaces}

The space utilisation studies of the education spaces were originally reported per component of space utilisation. Here, we report per space type. The data per component of space utilisation can be found in the Appendix. First, Table 4 displays the survey characteristics. In each year, the student population and the capacity in education spaces are different from the previous year, resulting in a gradual decrease in the number of seats/student. Furthermore, the composition of the portfolio has changed over the years. Each of these changes affects the reported results.

First, the overall performance across different space utilisation metrics is shown in the weeks that all studies can be compared: see Table 5 . Over the past five years, the space use has generally increased, with peaks in 2016-2017 and in 2019-2020. The scheduled frequency has increased from an average of $68 \%$ to $77 \%$, enabled by more efficient scheduling. The actual frequency has increased even more-from $59 \%$ to $74 \%$, due to an increase of scheduled activities and a reduction of no-shows. The actual occupancy has been fairly consistent

\begin{tabular}{|c|c|c|c|c|c|}
\hline & $2015-16$ & 2016-17 & $2017-18$ & 2018-19 & 2019-20 \\
\hline \multicolumn{6}{|l|}{ Portfolio vs. Survey } \\
\hline Seats / students & 0.87 & 0.86 & 0.82 & 0.83 & 0.82 \\
\hline Total amount of seats in education spaces & 18,300 & 18,532 & 18,539 & 19,306 & 19,555 \\
\hline Percentage of portfolio covered in survey & $69 \%$ & $67 \%$ & $69 \%$ & $72 \%$ & $71 \%$ \\
\hline \multicolumn{6}{|l|}{ Survey } \\
\hline Education spaces (number of spaces) & 130 & 136 & 144 & 157 & 157 \\
\hline Lecture halls & 36 & 31 & 31 & 31 & 31 \\
\hline Classrooms & 67 & 80 & 91 & 104 & 104 \\
\hline $\mathrm{PC}$ halls & 21 & 19 & 18 & 18 & 18 \\
\hline Exam halls & 6 & 6 & 4 & 4 & 4 \\
\hline Education places (capacity in seats) & 12,711 & 12,448 & 12,859 & 13,869 & 13,869 \\
\hline Lecture halls & 7,056 & 6,262 & 6,272 & 6,268 & 6,268 \\
\hline Classrooms & 2,924 & 3,908 & 4,408 & 5,422 & 5,422 \\
\hline PC halls & 1,471 & 1,232 & 1,324 & 1,324 & 1,324 \\
\hline Exam halls & 1,260 & 1,046 & 855 & 855 & 855 \\
\hline
\end{tabular}

Supporting strategic decisionmaking 
around $50 \%$ in these specific weeks. When compared to the target rates of the university, the 39,4 portfolio performs adequately in terms of frequency, but not in terms of occupancy. Unfortunately, the absence of scheduled occupancy data obscures what improvements may be made. It is not possible to identify whether the movements in the actual occupancy are caused by a better "match" of estimated attendance and capacity, by a higher student attendance, or both. It is also possible that they cancel each other out: students attend more scheduled activities, but the match between estimated attendance and capacity has worsened, or vice versa.

In Table 6 and Table 7, overviews are specified for lecture halls and classrooms. These tables show that the use of both space types differs from the portfolio average. Lecture halls have even higher scheduled and actual frequency rates than the average, of $90 \%$ and $87 \%$, respectively. The no-show percentage in these spaces is very consistent. When compared to space utilisation targets, the scheduled and actual frequency at times exceed the objective of $75 \%$. This is not a desirable situation, as it may lead to less desirable outcomes in the scheduling process. Therefore, more capacity is needed. Similar to the whole portfolio, the actual occupancy rates can be improved.

In classrooms, scheduled and actual frequency rates are less consistent, varying from 18 percentage points in scheduled frequency to 22 percentage points in actual frequency between years. The no-show percentage has declined since the start of the studies. This is presumably because schedulers estimate the group sizes of activities split across multiple classrooms more accurately. The actual occupancy is higher than in lecture halls, which is likely because it is easier to match group sizes to capacities in classrooms. When compared to space utilisation targets, scheduled and actual frequency rates in classrooms have at times

Space utilisation across surveyed education spaces (week 1.3-1.4)

\begin{tabular}{lccccc}
\hline Portfolio & $2015-16$ & $2016-17$ & $2017-18$ & $2018-19$ & $2019-20$ \\
\hline Scheduled Frequency & $68 \%$ & $81 \%$ & $70 \%$ & $66 \%$ & $77 \%$ \\
Actual Frequency & $59 \%$ & $75 \%$ & $66 \%$ & $61 \%$ & $74 \%$ \\
No-shows & $9 \%$ & $6 \%$ & $4 \%$ & $5 \%$ & $3 \%$ \\
Scheduled Occupancy & - & - & - & - & - \\
Actual Occupancy & $49 \%$ & $52 \%$ & $48 \%$ & $48 \%$ & $52 \%$ \\
\hline
\end{tabular}

\begin{tabular}{lccccc}
\hline Lecture halls & $2015-16$ & $2016-17$ & $2017-18$ & $2018-19$ & $2019-20$ \\
\hline Scheduled frequency & $79 \%$ & $87 \%$ & $82 \%$ & $80 \%$ & $90 \%$ \\
Actual frequency & $74 \%$ & $82 \%$ & $77 \%$ & $75 \%$ & $87 \%$ \\
No-shows & $5 \%$ & $5 \%$ & $5 \%$ & $5 \%$ & $3 \%$ \\
Scheduled occupancy & - & - & - & - & - \\
Actual occupancy & $48 \%$ & $49 \%$ & $49 \%$ & $45 \%$ & $50 \%$ \\
\hline
\end{tabular}

Table 6.

Space utilisation across all lecture halls (week 1.3-1.4)

\begin{tabular}{lccccc}
\hline Classrooms & $2015-16$ & $2016-17$ & $2017-18$ & $2018-19$ & $2019-20$ \\
\hline Scheduled frequency & $63 \%$ & $81 \%$ & $67 \%$ & $64 \%$ & $75 \%$ \\
Actual frequency & $52 \%$ & $74 \%$ & $63 \%$ & $58 \%$ & $72 \%$ \\
No-shows & $12 \%$ & $7 \%$ & $4 \%$ & $6 \%$ & $4 \%$ \\
Scheduled occupancy & - & - & - & - & - \\
Actual occupancy & $54 \%$ & $55 \%$ & $47 \%$ & $51 \%$ & $53 \%$ \\
\hline
\end{tabular}


met the objective of $75 \%$ and at other times not. Various factors have influenced these rates: the increasing student population, the space use of the shared education spaces, the addition of newly built classrooms, the introduction of new education programmes, etc. Again, the actual occupancy rates of classrooms may be improved.

Finally, the variability of the space utilisation across weeks is relevant. Figure 4, Figure 5, and Figure 6 show the average scheduled frequency rate, actual frequency rate and actual occupancy rate across all education spaces for each survey. The $x$-axis displays the week numbers; the $y$-axis displays the rate. Each of these graphs allows comparison per week across years. The scheduled and actual frequency show a specific pattern: after a slightly less busy first week, week 1.2 until 1.8 follow a similar pattern with a slight peak in week 1.4. Week 1.9 and week 1.10 show very low frequency rates, as they are exam periods. With regards to occupancy, a steady decrease is observed from week 1.1 until week 1.8, reflecting a decreasing attendance as the quarter progresses. The decrease continues in week 1.9-1.10 for education activities. This does not include exams, as they were excluded from the survey to minimise

\section{Scheduled frequency - All education spaces}

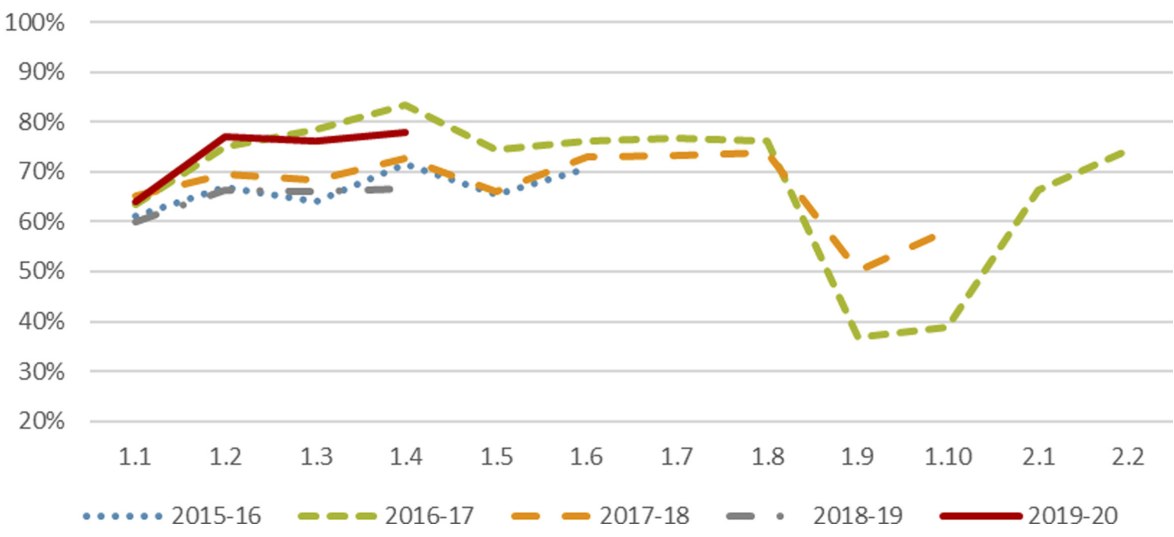

\section{Actual frequency - All education spaces}

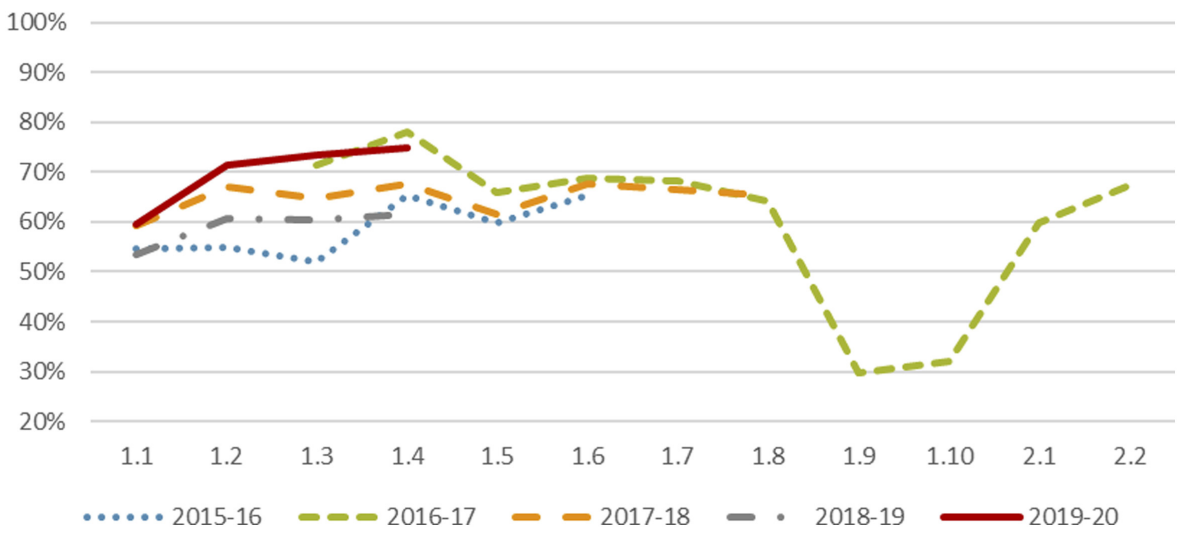

Supporting strategic decisionmaking

Figure 4. Average scheduled frequency of the zalenpoule; per year
Figure 5. Average actual frequency of the zalenpoule; per year 


\section{Figure 6.}

Average actual occupancy of the zalenpoule; per year
$100 \%$

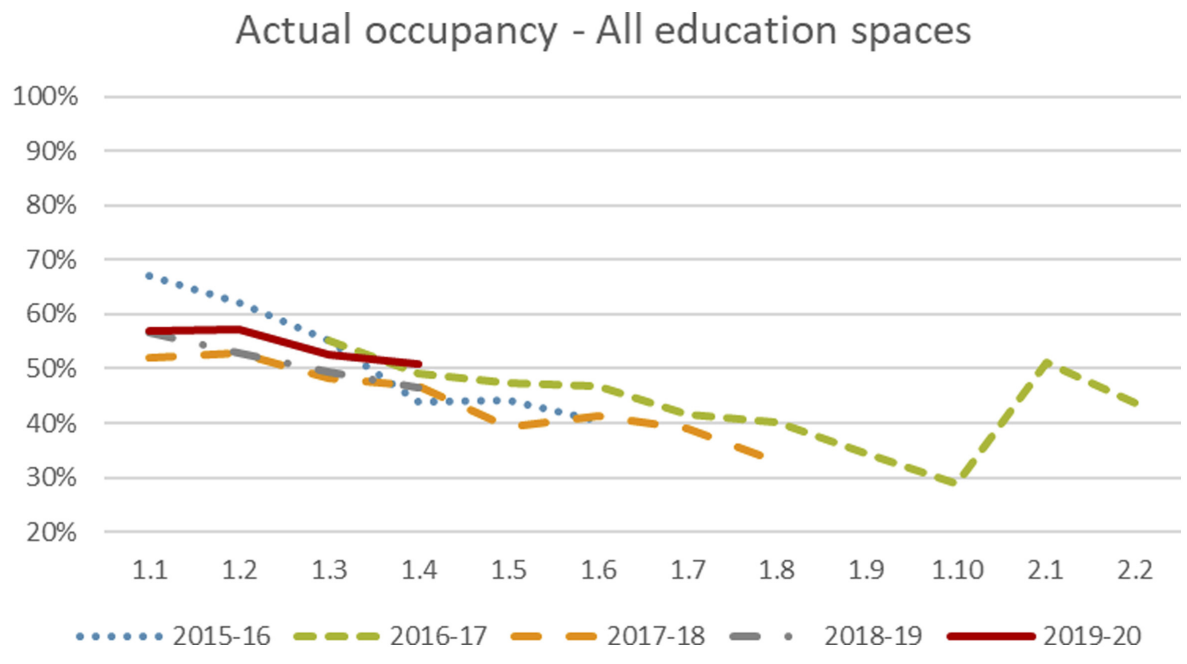

disturbance. Furthermore, surveying exams was found to be less relevant, as the scheduled and actual use of exam halls is very comparable.

These graphs can also be used to explain several considerations with regards to the setup of the utilisation studies. When the first study was conducted in 2015-2016, the shared view was that it should take place in the busiest period of the year. Therefore, the study was done in the first six weeks of the year. In the next years, there was a need to understand the space use across a whole quarter. These measurements have shown how the education spaces are used in exam weeks (1.9 and 1.10) when compared to regular education weeks. Those measurements also revealed that the pattern of week 5-8 was comparable to week 2-4. Interestingly, week 1 follows a specific pattern due to the start of the academic year and the start-up of some courses in week 2 instead of week 1 . Therefore, since 2018-19, the study has only been conducted from week 1 until week 4 .

\subsection{Study places}

The space use of study places has been reported in different ways throughout the years. Different analyses were made: e.g. per location, per hour of the day, per calendar week and per type of study place. Here, we report the occupancy per type of study place. Like the education spaces, the student population and amount of study places change each year and thus the study places/student ratio. This development is shown in Table 8 together with the part of the portfolio that is surveyed. As the table shows, the study places/ student ratio only includes type A, B and half of type C. Type B2 and a part of A2 are education spaces that are partly used as study places during exam periods and not counted during education weeks. The total number of available study places is thus much larger during exam periods, and thus the percentage of the portfolio covered is larger than $100 \%$.

The 2017-2018 study differs significantly in the amount of study places covered, but also in other aspects of its setup. In this study, a sample of study places in faculty buildings was surveyed, as there was a need to know how well these study places were used. In the 20182019 and 2019-2020 studies, the space use was surveyed across the whole portfolio. Furthermore, these studies did not measure week 1.10 (only week 1.8 and 1.9) and they divided occupancy into "occupied", "not occupied" and "occupied by belongings". Given the 


\begin{tabular}{|c|c|c|c|c|}
\hline$\underline{\text { Study places }}$ & 2017-18 & 2018-19 & 2019-20 & Supporting \\
\hline $\begin{array}{l}\text { Portfolio vs Survey } \\
\text { Study places/students } \\
\text { Total amount of study places }\left(\mathrm{A}+\mathrm{B}+0,5^{*} \mathrm{C}\right) \\
\text { Percentage of portfolio covered in survey }\end{array}$ & $\begin{array}{c}0.25 \\
5,650 \\
45 \%\end{array}$ & $\begin{array}{c}0.25 \\
5,900 \\
>100 \%\end{array}$ & $\begin{array}{c}0.24 \\
5,900 \\
>100 \%\end{array}$ & $\begin{array}{l}\text { decision- } \\
\text { making }\end{array}$ \\
\hline $\begin{array}{l}\text { Survey } \\
\text { A - Self-study } \\
\text { A2 - Self-study in PC halls } \\
\text { B - Touchdown } \\
\text { B2 - Touchdown in education spaces } \\
\text { C - Informal } \\
\text { Total }\end{array}$ & $\begin{array}{c}743 \\
\\
1,374 \\
\\
889 \\
3,006\end{array}$ & $\begin{array}{c}823 \\
1,287 \\
3,982 \\
1,437 \\
2,070 \\
9,599\end{array}$ & $\begin{array}{c}919 \\
1,279 \\
3,896 \\
1,437 \\
2,141 \\
9,672\end{array}$ & $\begin{array}{r}\text { Table } 8 . \\
\text { Survey characteristics } \\
\text { compared to portfolio } \\
\text { characteristics }\end{array}$ \\
\hline
\end{tabular}

differences between 2017-2018 and the subsequent years, only 2018-2019 and 2019-2020 will be used for comparison.

The occupancy for self-study places is shown in Figure 7, plus additional data for the other types in Table 9. There are large differences in the occupancy patterns of the different types so much so that it does not make much sense to report an average. Self-study places are occupied the highest, around $70 \%$ (occupancy + belongings) most of the day. Next is type A2 with rates between $50-60 \%$, then type $\mathrm{B}$ between $45-50 \%$, then $\mathrm{B} 2$ and $\mathrm{C}$ with rates around 20-25\%. Given these results, it makes sense to compare the occupancy rates for type A, A2 and $\mathrm{B}$ to a target of $\sim 70 \%$. The space use in type A2 and type B can be improved further by improving wayfinding to these study places and/or improving the study places themselves. For type B2 and C study places, another target may be considered given their multipurpose use.

A commonly observed phenomenon is that occupancy is below average in the early morning. Furthermore, as spaces become busier, the behaviour of leaving belongings to occupy study places increases. Aside from these observations, the further analysis of study places has yielded many insights. It shows which buildings are popular study locations and which are not. For the library, the analysis delves down to a room-level to show which study

\section{Occupancy of self-study places (type A)}

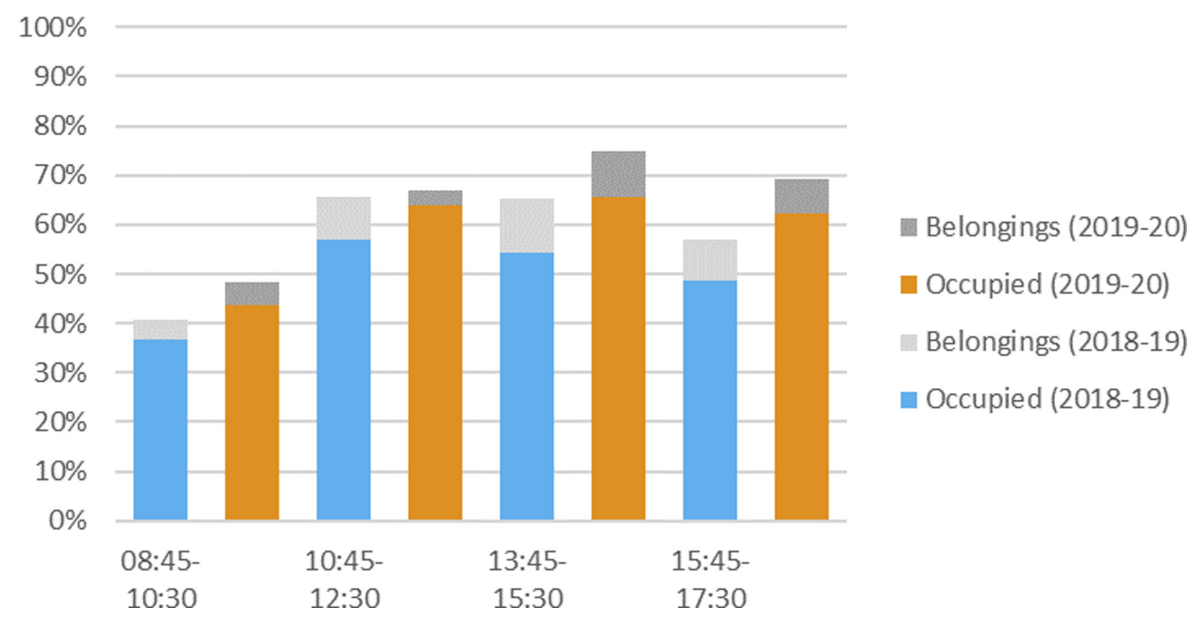

Figure 7.

Average occupancy for self-study places (week 1.8-1.9) 
$\mathrm{PM}$
39,4

458

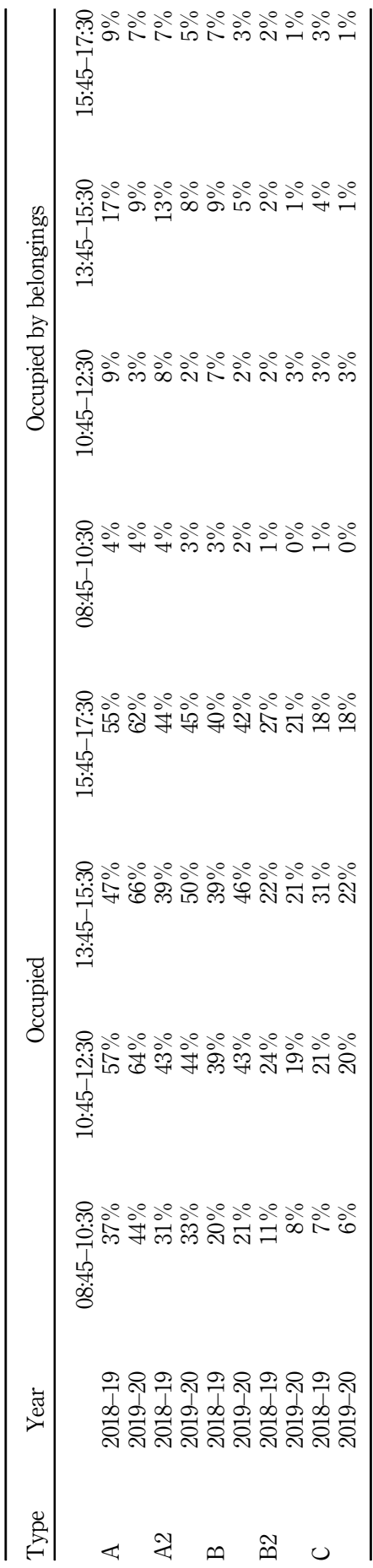

Table 9.

Occupancy per type of study place (week 1.8-1.9) 
places are not fully used. Also, occupancy patterns per day of the week and per week have been reviewed.

\section{Informing decision-making}

The policies on education spaces and study places and the space utilisation studies together have greatly impacted the university's campus strategy. The two figures below illustrate this impact. When the Roadmap was established as the framework for the management of education spaces and study places, plans were made to move a faculty from multiple buildings to one new building, and to renovate two large buildings between 2013 and 2022: see Figure 8. One of these renovations would lead to a large temporary capacity reduction (2,300 seats), before resulting in a slight increase. Given the norm of seats/student at the time (see section 5.2) and the increasing student population, this reduction was not feasible. The adjustment to the high population forecast coupled with the insights into which space types and sizes were needed changed this strategy.

Next, Figure 9 shows the development up to 2019: the student population has increased more than expected, student population forecasts have changed, and more education spaces have been realised. By realising education spaces of the right sizes and making adjustments in the education logistics process, the capacity is gradually decreasing towards 0.8 seat/ student. To accommodate increasing amounts of students two education buildings were planned: in 2018 (Pulse) and 2022 (Echo). Both pulse and echo were initiated during the adjustment of the campus strategy. During this adjustment, it was very helpful that information on the demand for education spaces could be quickly provided. Currently, it is being assessed if another building is needed around 2025.

The space utilisation studies deliver mostly additional insights to this process. In the past years the ratio in seats/student has declined and a further decline is expected. Year-by-year monitoring of the space use helps to understand the effects of this decline and provides input to discuss which ratio is desirable and achievable. Currently, the scheduled and actual frequency are mostly used in this analysis; however, in the future the scheduled occupancy rate may further detail how the match between estimated attendance and capacity may improve or worsen when the student population changes.

\section{Student population vs. Education space capacity}

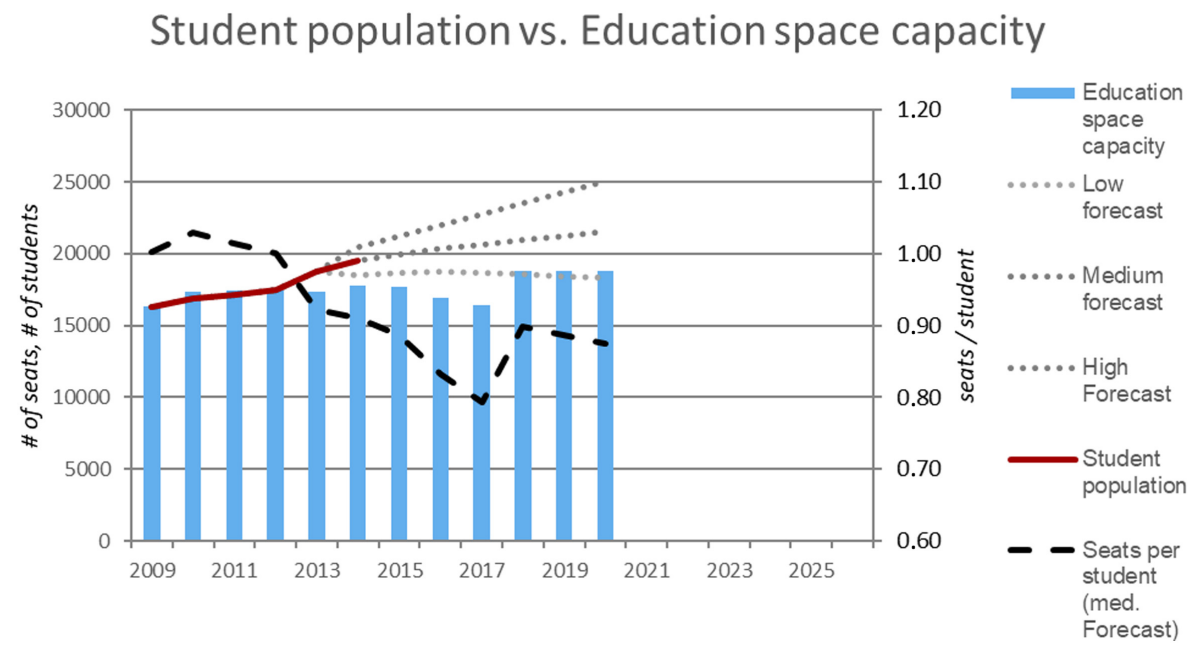

Supporting strategic decisionmaking

Figure 8.

Student population and forecast vs. the education space capacity and forecast (December 2014) 


\section{Student population vs. Education space capacity}

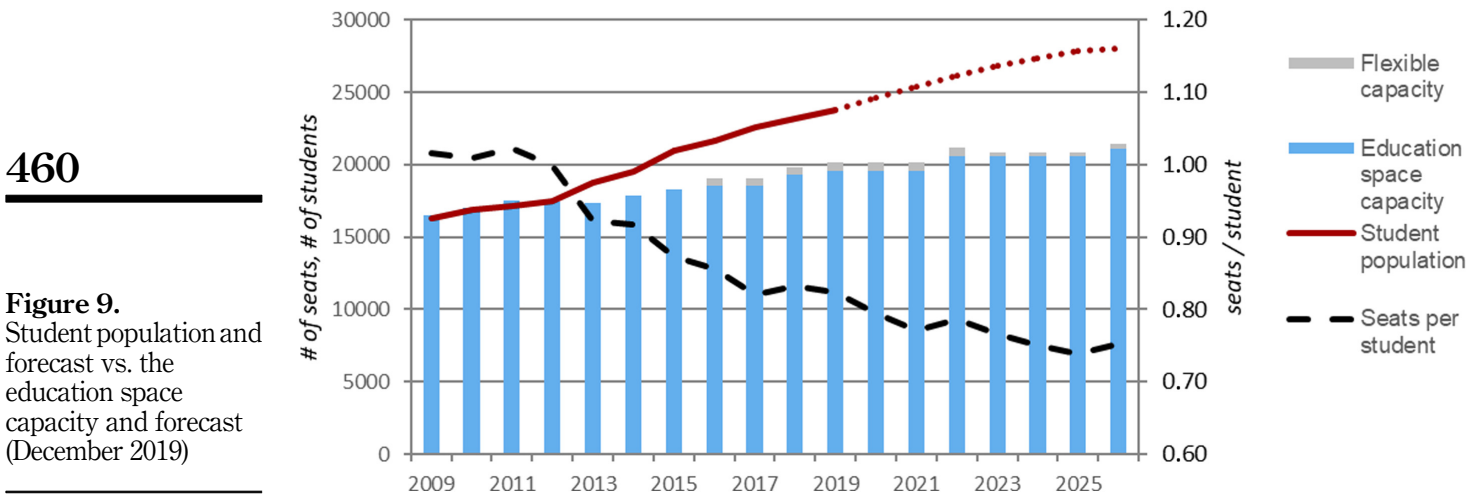

Figure 9.

Student population and forecast vs. the capacity and forecast (December 2019)

Figure 10.

Relation of space utilisation study to Programme Education Spaces
The planning of the university's study places is less strongly linked to the space utilisation studies and to the student population. In addition, space utilisation studies focussing on the use of education buildings in evenings and weekends are conducted. In consultation with the student council, the adequacy of the current capacity is determined and interventions are defined. The space utilisation studies provide necessary input for these discussions as evidence on the actual use of study places. As a result, various upgrades of existing study places on-campus were realised, and opening hours of facilities adjusted to demand. A consistent count of capacity of study places and a seats/student ratio for exam weeks would improve the usability of the space utilisation studies for decision-making.

More recently, the space utilisation studies have also become important input for the planning of short-term interventions. Figure 10 shows the planning of these processes, and Table 10 gives an overview of the planned and additional measures per year. When the first estimations on the estimated number of students for the next academic year become available (in January), it is compared to the forecast and available capacity. If the growth is higher than expected, then additional measures may be necessary. Here, the data from the space utilisation studies show to which extent the current spaces are used and where improvements can be made. Together with the data on the use of flexible capacity (spaces hired on demand by the university), it is determined which extra measures are needed. These are then realised during the summer months to minimise disturbance.

\begin{tabular}{|c|c|c|c|c|c|c|c|c|c|c|c|c|c|c|c|c|c|c|}
\hline \multirow[t]{2}{*}{ Activity } & \multicolumn{3}{|c|}{ Q3 } & \multicolumn{3}{|c|}{$\overline{Q 4}$} & \multicolumn{3}{|c|}{ Q1 } & \multicolumn{3}{|c|}{ Q2 } & \multicolumn{3}{|c|}{ Q3 } & \multicolumn{3}{|c|}{ Q4 } \\
\hline & Jul & Aug & Sep & Oct & Nov & Dec & Jan & Feb & Mar & Apr & May & Jun & Jul & Aug & Sep & Oct & Nov & Dec \\
\hline \multicolumn{19}{|l|}{ Academic year } \\
\hline \multicolumn{19}{|l|}{ Start of academic year } \\
\hline \multicolumn{19}{|l|}{ End of the academic year } \\
\hline \multicolumn{19}{|c|}{ Additional capacity needs } \\
\hline \multicolumn{19}{|l|}{ Identifying extra needs } \\
\hline \multicolumn{19}{|l|}{ Project preparation } \\
\hline \multicolumn{19}{|l|}{ Project delivery } \\
\hline \multicolumn{19}{|l|}{ Space utilisation study } \\
\hline \multicolumn{19}{|l|}{ Data collection } \\
\hline Analysis and reporting & & & & & & & & & & & & & & & & & & \\
\hline
\end{tabular}




\begin{tabular}{|c|c|c|c|c|c|}
\hline $\begin{array}{l}\text { Utilisation } \\
\text { study }\end{array}$ & $\begin{array}{c}\text { Academic } \\
\text { year }\end{array}$ & $\begin{array}{l}\text { Planned } \\
\text { mutations }\end{array}$ & $\begin{array}{l}\text { Additional proposed } \\
\text { measure(s) }\end{array}$ & Measures & $\begin{array}{l}\text { Supporting } \\
\text { strategic }\end{array}$ \\
\hline $2015-16$ & $2016-17$ & $\begin{array}{l}+200 \text { seats } \\
-400 \text { seats }\end{array}$ & $\begin{array}{l}\text { Increase use of flexible } \\
\text { capacity } \\
200 \text { seats in existing stock }\end{array}$ & $\begin{array}{l}\text { Increase use of flexible } \\
\text { capacity } \\
200 \text { seats in existing } \\
\text { stock }\end{array}$ & making \\
\hline \multirow[t]{2}{*}{$2016-17$} & \multirow[t]{2}{*}{$2017-18$} & \multirow[t]{2}{*}{-} & \multirow{2}{*}{$\begin{array}{l}\text { Increase use of flexible } \\
\text { capacity } \\
\text { Increase use of evening hours } \\
\text { Back-up plan for extra } \\
\text { capacity (200 places) }\end{array}$} & \multirow{2}{*}{$\begin{array}{l}\text { Increase use of flexible } \\
\text { capacity } \\
\text { Increase use of } \\
\text { evening hours }\end{array}$} & 461 \\
\hline & & & & & \\
\hline $2017-18$ & 2018-19 & $\begin{array}{l}+1,000 \text { seats } \\
-400 \text { seats }\end{array}$ & Back-up plan in case of delay & - & $\begin{array}{r}\text { Table 10. } \\
\text { Planned mutations and }\end{array}$ \\
\hline 2018-19 & 2019-20 & - & - & - & additional measures \\
\hline 2019-20 & $2020-21$ & - & Temporary units & T.b.d. & per academic \\
\hline
\end{tabular}

\section{Conclusion and discussion}

This paper reports on the space utilisation studies conducted at TU Delft. The study is unique, as it spans a whole portfolio across multiple years; it connects the outcomes of the study to space norms and organisational decision-making, and it clearly states the setup of the study. Over the years, it has supported campus managers with evidence to make decisions about the campus of the future.

The research question posed at the outset of this research was: what is the space use of education spaces and study places at TU Delft, and how does it inform campus decisionmaking?

For education spaces, data are collected on the scheduled and actual frequency and the actual occupancy. On average, the scheduled and actual frequency rates of all education spaces fall within the university's targets. In lecture halls, it is exceeded, suggesting additional capacity is required. The actual occupancy rates are well below the target of $60 \%$ scheduled occupancy. However, due to the absence of scheduled occupancy data it is impossible to accurately determine which measures will lead to a substantial improvement of the occupancy rate. This is a limitation of the study. The information on the use of on education spaces has helped to understand which amount of seats/student is achievable and desirable, and thus supported decisions to increase the education capacity both on the shortterm and long-term to accommodate the increasing student population.

For study places, a range of occupancy rates is reported, from $65-70 \%$ occupancy rate for type A study places to $20-25 \%$ for type $\mathrm{B} 2$ and $\mathrm{C}$ study places. The results suggest that the occupancy rates for type A, A2 and B study places can be compared to a target of $\sim 70 \%$, but for type $\mathrm{B} 2$ and type $\mathrm{C}$ this is difficult due to their multi-purpose use. When compared to the target, the occupancy of type A2 and B study places may be improved. The studies support continuous discussion to determine which interventions are needed and if the current capacity meets student's needs. However, more studies are needed to understand the relation between the space norms and space use of study places to set accurate targets and support decision-making.

In addition to the data for scheduled occupancy not being available, a limitation of this research is the absence of data on the underlying coefficients (see ch. 2.1). Although it is connected to space norms for education spaces and study places $(0.81$ and 0.23 seats per student, respectively), these norms are not well connected to underlying coefficients. Further research connecting the space norms to underlying coefficients for, e.g. planned frequency and occupancy rates or on-campus contact and learning hours is needed. 
Another issue for further research is data collection and analysis. In this study, and the studies discussed in section 2, data collection is done via manual counts. However, manual counts are expensive, time-consuming to collect and analyse and deliver only a snapshot of the actual space utilisation during the time of the study. Sensing methods (see, e.g. Valks et al. (2018; 2019) and many other studies) offer a more complete picture of space utilisation, may improve reliability of the studies. Still, the aspects which make this study unique should also be observed in future work based on real-time counts, as they improve the reliability and external validity of these kinds of studies. Another avenue for further research is data analysis of these studies. In this study, the data analysis is fairly simple, as most attention is paid to comparing year-by-year data and connecting it to decision-making. However, the application of in-depth analysis of these studies can yield many other useful insights for campus managers.

Finally, an issue underlying space utilisation studies is the exact determination of capacity, particularly for study places. Not only does it influence the results of the studies but also the determination of space norms. Especially the question how to count spaces that are not fully available as a study place needs to be addressed, both in terms of determining capacity and counting them during observations.

The authors hope that the study reported here may serve as a best practice for benchmarking by other universities, and as input for many other researchers that are looking for evidence on the planned and actual use of university facilities.

\section{Notes}

1. Note that this definition of actual frequency deviates from the earlier given definition, which is the number of hours used / total amount of available hours.

2. https://www.tudelft.nl/en/student/education/academic-calendar/

\section{References}

Abdullah, S., Ali, H.M. and Sipan, I. (2012), "Benchmarking space usage in higher education institutes: attaining efficient use", Journal of Techno-Social, Vol. 4, pp. 11-20.

Alghamdi, N. (2017), "Space, like time, is money: evaluating space utilisation in Saudi Arabian universities", in Filho, W.C., Frankenberger, F., Iglecias, P. and Consentino Kronka Mülfarth, R. (Eds), Towards Green Campus Operations. Energy, Climate and Sustainable Development Initiatives at Universities, Cham, Springer, pp. 3-40.

Arkesteijn, M.H. (2019), CRE Alignment. A Preference-Based Design and Decision Approach, Delft University of Technology, Delft.

Arkesteijn, M.H., Valks, B., Binnekamp, R., Barendse, P. and De Jonge, H. (2015), "Designing a preference-based accommodation strategy: a pilot study at Delft University of Technology", Journal of Corporate Real Estate, Vol. 17 No. 2, pp. 98-121.

Beyrouthy, C., Burke, E.K., Landa-Silva, D., McCollum, B., McMullan, P. and Parkes, A.J. (2008), "Threshold effects in the teaching space allocation problem with splitting", European Journal of Operational Research (EJOR), University of Nottingham, Nottingham.

Bowen, G.A. (2009), "Document analysis as a qualitative research method", Qualitative Research Journal, Vol. 9 No. 2, pp. 27-40.

De Jonge, H., Arkesteijn, M.H., Den Heijer, A.C., Vande Putte, H.J.M., De Vries, J.C. and Van der Zwart, J. (2009), Designing an Accomodation Strategy (DAS Frame), TU Delft Faculty of Architecture, Delft.

Den Heijer, A. (2011), Managing the University Campus, Eburon Academic Publishers, Delft.

Den Heijer, A. and Tzovlas, G. (2014), The European Campus - Heritage and Challenges, TU Delft, Delft. 
Downie, M.L. (2005), "Efficiency outcomes from space charging in UK higher education estates", Property Management, Vol. 23 No. 1, pp. 33-42.

Heywood, C. (2011), "Approaches to aligning corporate real estate and organisational strategy", ERES Conference, Eindhoven, 2011.

Heywood, C. and Arkesteijn, M.H. (2018), "Analysing fourteen graphical representations of corporate real estate alignment models", Journal of Corporate Real Estate, Vol. 20 No. 1, pp. 16-40.

Ibrahim, I., Yusoff, W.Z.W. and Sidi, N.S.S. (2011), "An effective management use of lecture room by space charging model", International Journal on Social Science, Economics and Art, Vol. 1, pp. 131-138.

Kadamus, J. (2013), "The state of facilities in higher education. 2013 benchmarks", Best Practices, and Trends, Sightlines, Guilford, CT.

Kasim, R., Nor, H.M., Masirin, M. and Idrus, M. (2012), “Assessing space utilisation for teaching and learning facilities at the higher education institution: a case study of G3 building, Universiti Tun Hussein Onn Malaysia”, OIDA International Journal of Sustainable Development, Vol. 4, pp. 125-134.

Khoo, M., Rozaklis, L., Hall, C.E., Kusunoki, D. and Rehrig, M. (2014), "Heat map visualizations of seating patterns in an academic library", IConference 2014 Proceedings.

Kumar, R. (1999), Research Methodology: A Step-by-step Guide for Beginners, Sage, London.

Lepori, B. and Reale, E. (2019), "The changing governance of research systems. Agencification and organisational differentiation in research funding organisations", in Simon, D., Kuhlmann, S., Stamm, J. and Canzler, W. (Eds), Handbook of Science and Public Policy, Edward Elgar Publishing.

McCann, L., Hutchison, N. and Adair, A. (2019), "External funding of major capital projects in the UK Higher Education sector: issues of demand, supply and market timing?", Journal of Property Research, Vol. 36 No. 1, pp. 97-130, doi: 10.1080/09599916.2019.1590453.

Merriam, S.B. (1998), Qualitative Research and Case Study Applications in Education, Jossey-Bass, San Francisco, CA.

NAO (1996), Space Management in Higher Education: A Good Practice Guide, National Audit Office, London.

Newell, G. and Manaf, Z. (2017), Education as an Asset Class, Western Sydney University, Penrith.

OECD (2019), Education at a Glance 2019, OECD Indicators, Paris.

Organ, M. and Jantti, M. (1997), "Academic library seating: a survey of usage, with implications for space utilisation", Australian Academic and Research Libraries, Vol. 28, pp. 205-216.

PCFC (1990), Guidance on Estate Management, Polytechnics and Colleges Funding Council, London.

Sankari, I., Peltokorpi, A. and Nenonen, S. (2018), "A call for co-working - users' expectations regarding learning spaces in higher education", Journal of Corporate Real Estate, Vol. 20 No. 2, pp. 117-137, doi: 10.1108/JCRE-03-2017-0007.

Schulze-Cleven, T. and Olson, J.R. (2017), "Worlds of higher education transformed: toward varieties of academic capitalism”, Higher Education, Vol. 73 No. 6, pp. 813-831.

Space Management Group (2006a), Review of Space Norms, Space Management Group, London.

Space Management Group (2006b), Space Utilisation: Practice, Performance and Guidelines, Space Management Group, London.

Stake, R.E. (1995), The Art of Case Study Research, SAGE Publications, Thousand Oaks, CA.

TEFMA. (2009), Space Planning Guidelines Edition, Tertiary Education Facilities Management Association, Hobart, Vol. 3.

TU Delft (2016), Campus NL - Investeren in de toekomst (commissioned by the VSNU and 14 universities), TU Delft, Delft. 
TU Delft (2018), "Cookbook education spaces. Requirements for education spaces TU Delft campus", available at: http://homepage.tudelft.n1/9c41c/Cookbook_Education_Spaces_v2_0.pdf.

UGC (1987), University Building Projects - Notes on Control and Guidance 1987 by UGC, The University Grants Committee, London.

Valks, B., Arkesteijn, M.H., Den Heijer, A.C. and Vande Putte, H.J.M. (2018), "Smart campus tools. Adding value to university goals by measuring real-time space use", Journal of Corporate Real Estate, Vol. 20 No. 2, doi: 10.1108/JCRE-03-2017-0006.

Valks, B., Arkesteijn, M. and Den Heijer, A. (2019), "Smart campus tools 2.0 exploring the use of realtime space use measurement at universities and organizations", Facilities, Vol. 37 Nos. 13-14, doi: 10.1108/F-11-2018-0136.

Yazan, B. (2015), "Three approaches to case study methods in education: Yin, Merriam, and Stake", The Qualitative Report, Vol. 20 No. 2, pp. 134-152.

Yin, R.K. (2002), Case Study Research: Design and Methods, SAGE Publications, Thousand Oaks, CA.

\section{Appendix}

\begin{tabular}{lccccc}
\hline Type & $2015-2016$ & $2016-2017$ & $2017-2018$ & $2018-2019$ & $2019-2020$ \\
\hline \multicolumn{2}{l}{ Reported average (week 1.1-1.8; 2.1-2.2) } & & & & \\
Lecture halls & $78 \%$ & $85 \%$ & $83 \%$ & $79 \%$ & $86 \%$ \\
Classrooms & $62 \%$ & $73 \%$ & $68 \%$ & $62 \%$ & $72 \%$ \\
PC halls & $65 \%$ & $70 \%$ & $59 \%$ & $52 \%$ & $67 \%$ \\
Exams & $57 \%$ & $64 \%$ & $63 \%$ & $66 \%$ & $55 \%$ \\
Total & $67 \%$ & $74 \%$ & $70 \%$ & $65 \%$ & $74 \%$ \\
Average week & $1.3-1.4$ & & & & \\
Type & $2015-2016$ & $2016-2017$ & $2017-2018$ & $2018-2019$ & $2019-2020$ \\
Lecture halls & $79 \%$ & $87 \%$ & $82 \%$ & $80 \%$ & $90 \%$ \\
Classrooms & $63 \%$ & $81 \%$ & $67 \%$ & $64 \%$ & $75 \%$ \\
PC halls & $68 \%$ & $72 \%$ & $65 \%$ & $53 \%$ & $72 \%$ \\
Exams & $59 \%$ & $62 \%$ & $66 \%$ & $67 \%$ & $56 \%$ \\
Total & $68 \%$ & $81 \%$ & $70 \%$ & $66 \%$ & $77 \%$ \\
\hline
\end{tabular}

Table A1.

Scheduled frequencyfor all education spaces and per space type
Exams 


\begin{tabular}{|c|c|c|c|c|c|c|c|c|c|c|c|}
\hline Type & $\begin{array}{l}2015- \\
2016\end{array}$ & $\begin{array}{l}2016- \\
2017\end{array}$ & $\begin{array}{c}2017- \\
2018\end{array}$ & $\begin{array}{l}2018- \\
2019\end{array}$ & $\begin{array}{c}2019- \\
2020\end{array}$ & $\begin{array}{l}2015- \\
2016 \\
\end{array}$ & $\begin{array}{c}\text { Reported } \\
2016- \\
2017 \\
\end{array}$ & $\begin{array}{c}\text { laverage } \\
2017- \\
2018 \\
\end{array}$ & $\begin{array}{c}\text { o-shows } \\
2018- \\
2019 \\
\end{array}$ & $\begin{array}{c}2019- \\
2020 \\
\end{array}$ & $\begin{array}{r}\text { Supporting } \\
\text { strategic } \\
\text { decision- }\end{array}$ \\
\hline \multicolumn{11}{|c|}{ Reported average (week 1.1-1.8; 2.1-2.2) } & making \\
\hline $\begin{array}{l}\text { Lecture } \\
\text { halls }\end{array}$ & $73 \%$ & $75 \%$ & $77 \%$ & $74 \%$ & $82 \%$ & $6 \%$ & $11 \%$ & $6 \%$ & $6 \%$ & $3 \%$ & \\
\hline Classrooms & $52 \%$ & $66 \%$ & $62 \%$ & $56 \%$ & $67 \%$ & $9 \%$ & $6 \%$ & $5 \%$ & $6 \%$ & $5 \%$ & 465 \\
\hline PC halls & $58 \%$ & $62 \%$ & $56 \%$ & $51 \%$ & $63 \%$ & $8 \%$ & $4 \%$ & $2 \%$ & $2 \%$ & $4 \%$ & \\
\hline Exams & $50 \%$ & $51 \%$ & $60 \%$ & $62 \%$ & $54 \%$ & $6 \%$ & $6 \%$ & $3 \%$ & $4 \%$ & $1 \%$ & \\
\hline Total & $59 \%$ & $68 \%$ & $65 \%$ & $59 \%$ & $70 \%$ & $8 \%$ & $6 \%$ & $5 \%$ & $6 \%$ & $4 \%$ & \\
\hline \multicolumn{6}{|c|}{ Average week 1.3-1.4 } & \multicolumn{5}{|c|}{ Average week 1.3-1.4 (no-shows) } & \\
\hline Type & $\begin{array}{l}2015- \\
2016\end{array}$ & $\begin{array}{l}2016- \\
2017\end{array}$ & $\begin{array}{c}2017- \\
2018\end{array}$ & $\begin{array}{l}2018- \\
2019\end{array}$ & $\begin{array}{c}2019- \\
2020\end{array}$ & $\begin{array}{l}2015- \\
2016\end{array}$ & $\begin{array}{c}2016- \\
2017\end{array}$ & $\begin{array}{c}2017- \\
2018\end{array}$ & $\begin{array}{c}2018- \\
2019\end{array}$ & $\begin{array}{c}2019- \\
2020\end{array}$ & \\
\hline $\begin{array}{l}\text { Lecture } \\
\text { halls }\end{array}$ & $74 \%$ & $82 \%$ & $77 \%$ & $75 \%$ & $87 \%$ & $5 \%$ & $5 \%$ & $5 \%$ & $5 \%$ & $3 \%$ & \\
\hline Classrooms & $52 \%$ & $74 \%$ & $63 \%$ & $58 \%$ & $72 \%$ & $12 \%$ & $7 \%$ & $4 \%$ & $6 \%$ & $4 \%$ & $\begin{array}{l}\text { Table A2. } \\
\text { tal frequency and }\end{array}$ \\
\hline PC halls & $59 \%$ & $69 \%$ & $62 \%$ & $52 \%$ & $69 \%$ & $9 \%$ & $3 \%$ & $2 \%$ & $1 \%$ & $3 \%$ & $\begin{array}{l}\text { Actual frequency and } \\
\text { no-shows-for all }\end{array}$ \\
\hline Exams & $53 \%$ & $57 \%$ & $63 \%$ & $64 \%$ & $56 \%$ & $6 \%$ & $5 \%$ & $3 \%$ & $3 \%$ & $1 \%$ & $\begin{array}{l}\text { no-snows-1or all } \\
\text { education spaces and }\end{array}$ \\
\hline Total & $59 \%$ & $75 \%$ & $66 \%$ & $61 \%$ & $74 \%$ & $9 \%$ & $6 \%$ & $4 \%$ & $5 \%$ & $3 \%$ & per space type \\
\hline Type & & 2015-2016 & & 2016-2017 & & 2017-2018 & & 018-2019 & & 019-2020 & \\
\hline \multicolumn{12}{|c|}{ Reported average (week 1.1-1.8; 2.1-2.2) } \\
\hline Lecture halls & & $51 \%$ & & $44 \%$ & & $45 \%$ & & $50 \%$ & & $54 \%$ & \\
\hline Classrooms & & $54 \%$ & & $49 \%$ & & $44 \%$ & & $54 \%$ & & $56 \%$ & \\
\hline PC halls & & $57 \%$ & & $51 \%$ & & $46 \%$ & & $50 \%$ & & $49 \%$ & \\
\hline Exams & & $35 \%$ & & $40 \%$ & & $33 \%$ & & $49 \%$ & & $45 \%$ & \\
\hline Total & & $52 \%$ & & $47 \%$ & & $44 \%$ & & $51 \%$ & & $54 \%$ & \\
\hline \multicolumn{12}{|c|}{ Average week 1.3-1.4 } \\
\hline Lecture halls & & $48 \%$ & & $49 \%$ & & $49 \%$ & & $45 \%$ & & $50 \%$ & \multirow{5}{*}{$\begin{array}{l}\text { Table A3. } \\
\text { Actual occupancy for } \\
\text { all education spaces } \\
\text { and per space type }\end{array}$} \\
\hline Classrooms & & $54 \%$ & & $55 \%$ & & $47 \%$ & & $51 \%$ & & $53 \%$ & \\
\hline PC halls & & $53 \%$ & & $50 \%$ & & $50 \%$ & & $52 \%$ & & $49 \%$ & \\
\hline Exams & & $24 \%$ & & $49 \%$ & & $31 \%$ & & $55 \%$ & & $45 \%$ & \\
\hline Total & & $49 \%$ & & $52 \%$ & & $48 \%$ & & $48 \%$ & & $52 \%$ & \\
\hline
\end{tabular}

\section{Corresponding author}

Bart Valks can be contacted at: b.valks@tudelft.nl

For instructions on how to order reprints of this article, please visit our website:

www.emeraldgrouppublishing.com/licensing/reprints.htm

Or contact us for further details: permissions@emeraldinsight.com 